\title{
6 \\ Multi-level Governance as Political Theory
}

\author{
Russell Kerr
}

\section{Train kept a rollin'}

In the 2013 film, Snowpiercer, the tiny portion of humanity remaining after a geo-engineering incident triggers a global ice age are confined to a train circumnavigating the earth once a year. Korean director Bong Joonho's adaptation of the 1982 French graphic novel, Le Transperceneige, can easily be seen, as the comic can be read, as an allegory. But is it an allegory of potential catastrophe - a return to a Hobbesian political state - or is it an allegory of a current political condition?

A case for both readings can be readily made. Like the standard version of Thomas Hobbes's Leviathan (1651), outside the train (Commonwealth), life is unendurable: security resides only in the protection of the sovereign. In the film, the train's captain and builder of its 'sacred' engine (compare the Hobbesian state as 'mortal god'), Wilford, could play the role of sovereign. ${ }^{1}$ Moreover, just like Hobbes's conception of sovereignty, some

1 The film changes character names and alters roles from the graphic novel; e.g. in the comic, Wilford is Forrester, an engineer who is more isolated from the rest of the train than its tyrant (see Lob and Rochette (2014), especially pp. 102-10). The three-volume French original has been translated into a two-volume English-language set. 
members of humanity remain in a condition at once inside and outside the state of nature; those confined to the back of the train, where life is indeed 'poor, nasty, brutish and short'.

Alternatively, the train can be seen as an allegory of current conditions of extreme inequality in security, wealth, privilege and distractions in advanced liberal polities. The train (a Scheherazade-like 1001 carriages, each one a story) is a linear hierarchy, with a rigid order separating those at the back ('Know your place, keep your place' threatens a Thatcher-esque bureaucrat) from the middle (classes) and the tyrant alone at the head of the train. Once the film's main character, Curtis, fights his way to the front of the train in the hope of obtaining justice for those at the back, he is offered the tyrant's role. Along the way, those who died in the struggle to advance Curtis turn out to be the numerical sacrifices that Wilford has calculated are needed to maintain the social order (that same bureaucrat announces the exact number of who will die early in the piece).

According to this latter interpretation, political freedom is at issue: Curtis has betrayed the revolution, or the revolution is betrayal. At the same time, the story shares a structure with another tale of money, democratic promise and betrayal: The Wizard of $\mathrm{Oz}$. Here, Curtis/Dorothy struggles to make it to the singular place of the master of the machinery (Wilford/ the Wizard), only to be shown that, all along, he/she has the power to realise what he/she sought out power to achieve. The lesson is not only political; it is wrapped in an economic debate. The key here is that, like the distribution and display of wealth and power in the film (and a wicked witch in both), Frank Baum's The Wonderful Wizard of $\mathrm{Oz}$ (1900) is a tale concerned with value, debt and the insecurity of currency (in the film the main currency is a drug, while it is free silver in Baum's Oz). ${ }^{3}$ It would certainly be possible to construct an analogy with current economic circumstances in the European Union (EU).

Which interpretation to choose: the allegory of a return to Hobbes or an allegory of contemporary reality? Must we choose? According to the vast bulk of current social and political writing, we have to choose, because a polity such as the EU cannot be both a Hobbesian state and a contemporary one. My illustration of Snowpiercer is meant to suggest

2 c.f. Hobbes (1985: 186).

3 For more on late 19th-century American populism, fiat money and the Wizard of $\mathrm{Oz}$, see Dighe (ed.) (2002); Rockoff (1990) and Ziaukas (1998). 
that, in fact, not only can we not choose between these allegorical images, but also we should not. The remainder of this essay attempts to explain why.

The argument proceeds in three steps. The first step outlines the case for the EU as a move away from sovereignty-centred politics and towards governance. This case involves two dimensions: it is a claim to novelty, or a new conception of politics, and it is a claim to a new conception of 'the people', or at least to a concept of 'variable publics' understood to be at odds with the classical notion of the fixed public defined by its citizen status in a singular state. Combining these two claims, multi-level governance (MLG) may claim to reinvigorate civic engagement and thus potentially redeem the 'democratic promise' (Goodwyn 1976) that has eluded the polities of advanced liberal societies. (This promise can be traced to the American populist political economy to which The Wizard of $\mathrm{Oz}$ responds.)

The second step is to show that the rhetorical distinctions MLG employs to make its claim to novelty and democratic promise lead to several debilitating results. Adapting a Kantian split between sovereignty and government implies placing some of our contemporaries in the past; as a result, MLG shares with liberal and neoliberal theory a view of the future where no-one's place is certain. Dividing past from future in the name of novelty - and in opposition to sovereignty - also raises questions about MLG's ability to account for how it gets from there to here. The rhetoric of change from a 'world dominated by sovereignty' suggests that governance tends to rely on a non-causal sense of transformation. This non-causal form of reasoning sits uneasily with MLG's dominant idea of political bodies. At the same time, non-causal reasoning is at the centre of Hobbes's argument for sovereignty, and can act as a point of similitude between MLG and sovereignty.

The third step elaborates part of Hobbes's argument for sovereignty. Specifically, an overview of Hobbes's rhetorical re-description of bodies shows that sovereignty does not consist in positing a 'constitutive outside' to the commonwealth in the form either of a state of nature or system of states. ${ }^{4}$ On the contrary, Hobbes's political subjects only appear as such in the perpetual instants of crossing boundaries with these outsides. 
Thus, sovereignty is not helpfully understood in opposition to MLG. In this chapter, MLG is treated as a boundary-crossing activity. ${ }^{5}$ This activity includes crossing boundaries with sovereignty. But the main innovation I propose, against the grain of long-standing habit, is to treat sovereignty too as a boundary-crossing conception of politics.

\section{Sovereignty vs governance}

The sovereignty/governance opposition is most apparent, developed and sharp in analyses of the EU. Take the example of Bob Jessop's rich concepts of 'meta-' and 'multi-scalar' governance. While EU member governments may take on the coordinating role of 'meta-governance', there can be no question of a return to a 'stable equilibrium' of a final form of metagovernance, which would be tantamount to a return to sovereignty as a singular mode of rule and subjection:

But there is no point at which a final metagovernance instance can be established to coordinate the myriad subordinate forms of governance - this would re-introduce the principle of sovereignty or hierarchy that growing social complexity and globalization now rule out (Jessop 2005: 66). ${ }^{6}$

For some analysts, sovereignty is less a principle than a problematic. Measured according to the standard of Hobbes's classical account of sovereignty as necessarily undivided, Fritz Scharpf (2012) demonstrates well the dilemmas of the EU in conditions of divided sovereignty and crisis. Scharpf (2012: 29-30) points out that governing via the market leads to both an intensification of the euro crisis and a legitimacy crisis. Seen from the vantage point of divided sovereignty (which leads to his salient discussion of 'output legitimacy'), the EU might well be seen in Hobbesian terms as 'facing the constant danger of fragmentation and dissolution' (Hänninen 2014).

\footnotetext{
5 See Daniell and Kay.

6 In the MLG literature, this beginning may be prefaced by a quasi-historical account of the fate of the political community from its putative origins in classical Greece (e.g. Cerny 2009), or it may not. In either case, the line drawn between 'the sovereign state' and the varieties of governance supports the legitimation of governance as a conceptual object.
} 
Scharpf's response to this dilemma is to lower the 'political salience' of legitimation issues in times of crisis, essentially by governing through the market less (see also Hänninen 2009). Others, however, begin from an assumption that the Hobbesian paradigm belongs to the past. Consider the conclusion to the influential Hooghe and Marks (2003: 241):

Political science has had far more to say about how collective decisions can and should be made than about for whom they can and should be made. Answers to the 'how' question have narrowed because there is no legitimate alternative to liberal democracy. Debate centers on the merits of alternative democratic designs. But there is little consensus about jurisdictional design - the 'for whom' question. Central states are shedding authority to supranational and subnational authorities, but what kinds of jurisdictional architecture might emerge?

While granting the centrality of the problem of authority from the outset of their article, Hooghe and Marks (2003) treat the issue as an organisational one throughout, deferring the question of what authorises this treatment. Nonetheless, the authors engage in a practice of temporal differentiation that permits a particular conception of politics to appear as the solution to their future-oriented question.

In their conclusion, the novelty of MLG is not so neatly boxed in a return to the past. After all, their terms are familiar to 19th-century liberal thought, ${ }^{7}$ which divides discussion of politics into a matter of politics-as-sphere ('scope') and politics-as-activity ('how'). The division, of course, is enabled by the future-oriented claim of 'no alternative'. The future features a further division between the relative authority of bodies 'above' and 'below' the national. This triple division (and its 'vertical' and 'horizontal' spacing), in turn, permits one available political option: (legitimate) dispute will be over 'who' the people are in a given area of political decision-making. If it is an axiom of contemporary politics that 'the people are always missing' (Deleuze 1993: 220), the picture drawn by Hooghe and Marks goes some distance towards creating an image of the people.

Hooghe and Marks's implicit solution to the political founding problem resonates with discussions in contemporary political theories of federalism, ${ }^{8}$ for which the MLG concept can have a particular salience.

7 c.f. Palonen (2003: 171).

8 See, for example, Goodin (2008, especially p. 151). 
Neither governance nor federalist discourse is inclined to acknowledge its authorising and legitimating work. Nonetheless, the aspiration to identify the demos (the people who are constituted to participate in politics) through decision-making authority is a feature shared with sovereignty as a discourse of political founding. The shape of that authority, and the routes it takes (horizontal-vertical / ascending-descending), are the object of a properly topological analysis (see esp. Hänninen 2014).

Hooghe and Marks return to one version of past political theory (19th-century liberalism) to counter another (Hobbes's conception of sovereignty). This return is carried out in the name of a future-oriented conception of the demos and democratic design. At the same time, it is an attempt to incorporate a claim to novelty into its design. Such a claim is required not least by MLG's effort to differentiate itself from sovereignty. Nonetheless, claims to novelty are not new: political theory has long worked according to a variety of claims to novelty, and Hobbes's argument for sovereignty is among them. ${ }^{?}$

Similarly, Jessop's acknowledgement of definition by negation (see footnote 9) is another opening to a formulation of governance as novel, particularly in contrast to state and supra-state sovereignty. Jessop goes on to observe that, while the role of governments at all levels in metagovernance may increase state capacity in some dimensions, analysts are witnessing:

a trend towards the de-statisation of the political system. This involves a shift from government to governance on various territorial scales and across various functional domains (Jessop 2005: 65)..$^{10}$

Tellingly, Jessop's 'shift' in the passage above is glossed as 'alternative' in Stephen George's contribution to the same volume:

Placing multi-level governance in the context of the intergovernmental/ supranational debate in EU studies allows an informed understanding of it as an alternative to state-centred perspectives (George 2005: 125).

9 Evidence of argumentation from novelty is readily available in the MLG literature. In the case of the EU, Philippe Schmitter (1998: 132) speculates whether 'something qualitatively different' than a sovereign order is emerging. Sharing Schmitter's concern for a conceptual and analytic response, Bob Jessop (2005: 61) observes that, at present, 'it is much clearer what the notion of governance excludes than what it contains' (c.f. Bache and Flinders 2005: 96; see also Jessop 2009).

10 See also Héritier and Rhodes (2011). 
My focus here is on the equivalence of 'shift' and 'alternative' in accounts of the difference between 'state-centric' and governance modes. Clearly, the equivalence is a response to conditions under which novelty appears as both a problem and an opportunity. How a shift from government to governance is equivalent to an alternative between them is a question of some theoretical and empirical interest. However, that is not my main concern. Whatever else they may be, as descriptions, these formulae do not serve to further understanding of what has 'shifted' or become an 'alternative' precisely; or how, or under what conditions, or for whom. As explanations amenable to any sort of causal analysis, these characterisations are of little specific value.

\section{Sovereignty off the rails}

On the other hand, these distinctions have a strong rhetorical value. The government/governance division can be seen as a question of re-description (c.f. Palonen 2002); that is, as a matter of political rhetoric, such as Quentin Skinner (1996) and Patricia Springborg (2010) find in their different ways within Hobbes's classic work on sovereignty. It could also be judged as an instance of indeterminacy (Hänninen 2014), insofar as the vexed question of the EU as a polity can be approached on a single line of reasoning from both a past-bound ('shift') and future-bound ('alternative') perspective.

Here, the founding acts of governance occur well within the bounds of the distinction -credited to Jean Bodin in the early 17 th century (Lee 2013) but found in Hobbes (1651) and still in Immanuel Kant at the end of the 18th century - between sovereignty and government. In Kant's paradigmatic version in his 1795 essay, Perpetual Peace, 'the forms of a state (civitas) can be divided either according to the [number of] persons who possess the sovereign power or according to the mode of administration exercised over the people by the chief, whoever he [sic] may be' (Kant 1975: 95).

The first term in this division is sovereignty and, while important, it is far less a matter of concern to the governed. The second, which concerns the exercise the state makes of its power, is the mode of government. Government, Kant goes on to insist, is either republican (where the executive is separated from the legislative) or despotic (where it is not). Democracy, we should note, is for Kant a species of the latter. This is 
because 'all' (citizens as a single will), who are 'not quite all' (some citizens may disagree), establish an executive power over all. Democracy is thus for Kant in contradiction with freedom (Kant 1975: 96).

It is not difficult from this distinction to see that 'the hierarchical state' in MLG discourse fits Kant's account of sovereignty. In the MLG account, sovereignty is then conflated with government in the state. That is, while Kant's republic corresponds well to what is now meant by representative democracy (a form of government in Kant's terms), the MLG literature sees government as a species of the state, and thus of sovereignty. Once this conflation has been made, governance reappears within the sovereignty/government distinction to fulfil the role that government is no longer adequate to carry out. The distinction, however, lacks one term: sovereignty is subtracted, now relegated to the never (hopefully) to return past. Governance alone remains.

Such an effective logic of founding bears comparison with those of Hobbes, Locke and Rousseau, to name only the most obvious. Three common features of this logic of founding should be noted. First, it proceeds by means of splitting, of making authoritative distinctions, within a spatial domain (the political community). Second, founding invokes a split view of time: some aspects of the present ('sovereignty' in MLG's case) are relegated to the past, others to the present ('government') and some are granted the future ('governance'). Third, the account takes place in the name of an authorised and authorising people ('citizens').

This schematic view of governance as political theory requires, however, a further step. In the discussion above, Kant's distinction between sovereignty and government occurs within the single state. Kant's essay is not often remembered for this distinction, but rather for its attempt to outline the requirement that republican states - which alone promise freedom for their citizens - realise a federation. In other words, there is an 'international' imperative to Kant's project, without which his characterisation of freedom in a single state is without force.

Anthony Pagden, among others, has not hesitated to see in this federation the model for the imposition of a universalist mode of governance that is now familiar in institutions ranging from the International Monetary Fund, World Bank and international non-government organisations to the United Nations human rights regime (Pagden 1998; see also the conclusion to Pagden 2001). There is a considerable cost to this singular 
universalism, however, and that is a constitutive fracturing of the world populations governed by states into those with a governable future and those for whom this future is doubtful. ${ }^{11}$

These fractures are enabling, and thus can be characterised as temporal and spatial borders that the community of humanity, as a community of state-bound citizens, must cross to realise the future promise of freedom. Borders, in others words, matter. Moreover, they matter 'politically': those contemporaries who embody the past in the present ('medieval Muslims', 'non-modern societies', 'rogue states' etc.) may be legitimately governed by paternalism/coercion until they are ready to accede to the level achieved by states governed through the freedom Kant requires for private property, security of contract and thus 'peaceful commerce' to flourish everywhere (Helliwell and Hindess 2011, 2015).

In developments of some moment for the concept of MLG and its relation to the politics of the market, contemporary political theory has sought to retain Kant's affirmation of peaceful commerce among republics in the widely disputed 'democratic peace thesis'. ${ }^{12}$ One means of doing so has been to jettison at least some of Kant's 'metaphysics' in favour of a 'political liberalism'. ${ }^{13}$

But this is where things fall apart. As far as future-oriented politics goes, such a manoeuvre appears self-defeating. As Helliwell and Hindess (2015) have admirably demonstrated, attempts such as Thomas Pogge's effort

11 As Helliwell and Hindess (2015) demonstrate, Kant's account of progress towards an ideal political community depends upon placing some members of humanity closer to that future goal, and others (notably 'the Tahitians', who are placed at the developmental level of sheep) more distant from it. Echoing Jessop's implicit division of contemporary global politics into past, present and future, a cosmopolitan vision of humanity as a political constituency operates along a single (developmental) line that consists of fractures:

Kant is able to bring all of humanity together into a single cosmopolitan progression only by distributing its diverse sections along one developmental ladder. What we have here is a matter of cosmopolitan unification by a no less cosmopolitan differentiation (Helliwell and Hindess 2015).

12 See, for example, Doyle (1983a, 1983b, 1986), Cavallar (2001), MacMillan (2004), Rosato (2003).

13 Most notably in Rawls (1985, 1996, 1999). 
to appropriate Kant's cosmopolitan program shorn of its metaphysical foundations result in a view of future politics without guarantee of improvement. ${ }^{14}$

Having placed itself at the apex of time, nothing guarantees that contemporary liberal thought will remain there, or even that this apparently privileged site will remain available. At the same time, the developmental, differential view of humanity underwriting the cosmopolitan vision works unchecked. These twin dynamics challenge modes of political thought that take their bearings from a distinction with sovereignty, even as they attempt acts of founding familiar in style to 'sovereignty-centred' political theory.

The challenge is particularly felt in comparisons of governance and neoliberalism. If an absence of a future guarantee is a dilemma for governance, neoliberalism might appear well placed to profit from this void (which neoliberals gloss as 'anarchy'). For example, Samuel Huntington (2006: 1) begins his 1968 study of 'political order in changing societies' by asserting that the form of government (in the Kantian sense) matters little: what counts is 'effectiveness'. Cognate arguments can be found in Mancur Olson (Olson 1971, 1993; McGuire and Olson 1996), who is well known for his 'collective action problem', as well as in Francis Fukuyama's (2008) review of the Regional Assistance Mission, Solomon Islands (RAMSI).

To the 'failed state' problem of the Solomon Islands, Fukuyama recommends a form of 'shared sovereignty' with more capable states. A 'state-building' project must recognise that the Solomon Islands are emerging from a 'state of nature' (anarchy) requiring the 'helping hand' of properly ordered commonwealths. A profound politics is at work in this shallow formulation. Fukuyama appears to discuss two states, the failed and the capable. But are these two states or one?

14 See Pogge (1992, 1994, 2002). The failure of future guarantee follows because Pogge's design: lacks the original's optimistic teleology. As a consequence, it also lacks [Kant's] belief that current political ideals are still far from the best they can be; in Pogge's vision contemporary ideals of freedom and democracy are presented as the ultimate political values to which all sections of humanity should unquestioningly aspire (Helliwell and Hindess 2015). 
The characterisations of 'anarchy' and 'capability' mirror steps in Hobbes's anti-historical tale ${ }^{15}$ of the founding of the sovereign state. In Fukuyama, as in the standard view of Hobbes, a movement of necessity to escape disordered violence establishes the link between anarchy and capability. The link between steps can also be reasoned as temporal: 'the condition of anarchy' and its inhabitants constitute the prehistory of the commonwealth. Like Hobbes, for whom American Indians represent a minimal form of self-government in an indefinite European past, Fukuyama defines Melanesian social organisation as belonging to a past that Europeans have surmounted:

Segmentary societies are a coherent and stable form of social organization, but in Europe they were superceded at a fairly early point by more modern forms of political organization not based on kinship. Segmentary societies could not meet the challenges of large-scale social integration in a region characterized by persistent warfare and expanding trade (Fukuyama 2008: 2).

In a development not dissimilar to the way in which governance can emerge from a splitting of sovereignty and government, in shared sovereignty two states are split and rejoined to conjure one: the singular story of the sovereign state. In part, this conjuring is achieved by replacing definite history with a developmental concept of 'society', buttressed by a hierarchy of capacities. Those capacities are ranged in a temporal order of strength, where capacities located in the past are the weakest. Given these affinities with a rationality of violence in international relations as a practice of founding, MLG's normative urge runs the risk of collapsing into the 'might makes right' counterargument familiar to political theory since Thrasymachus' early challenge to Socrates in Plato's Republic.

The discussion above illustrates a critical point: claims to comparative efficiency, capability and capacity for 'learning' ${ }^{16}$ may well depend upon a politics of founding whose major feature - a division of populations into states governed according to a division determined suitable for a future invoked as necessary but also impossible - is shared with the classical claims to sovereignty it seeks to avoid.

15 Contrary to the view put forward by John Locke, Hobbes did not argue that 'the state of nature' is an historical condition; indeed, he argued against practical history as a means of deducing an enduring commonwealth (see, among others, Sorell (2000: 83-84).

16 c.f. the critical remarks in Dale (2004: 189). 
Nowhere in the MLG literature is the legitimating logic of these temporal and spatial divisions more apparent than in debates over the relationship between MLG and its constituency, or its (variable) publics. As a ramification of Kant's conception of freedom, the matter tends to resolve into the question of how, in the $\mathrm{EU}$, democratic governance reflects economic governance, or governing 'in the name of the market' (Hänninen 2013). As a corollary, governing 'in the name of the people' will require authoritative mechanisms for representation in decisionmaking on multiple levels and at different scales.

As a political logic, one attuned to the need to authorise and legitimate its forms and vocabulary, MLG is challenged by problems associated with 'state-centric' political theories. In as much as MLG claims to depart from 'sovereignty-centred' thinking, a double challenge thus presents itself. Considered as a form of political theory, MLG displays the hallmarks of a practice of founding. Nonetheless, as again the example of Kant suggests, there is considerable doubt as to whether this can be accurately described as a founding in the classical style of the self-sufficient community of the singular state. ${ }^{17}$

\section{Governmental freedom}

The absence of a causal founding logic in MLG is not due in the first instance to appeals to complexity and network logic. Some of these accounts may be more or less plausible if - and only if - political bodies are granted an existence prior to their conditions of action, and they are credited as sources of (rational) agency, however 'interdependent' such agency may be pictured.

17 In part, the doubt arises because of the tension in liberal thought between republicanism and democracy, formalised by Kant. Multi-level government sits in an uneasy position within this tension. For example, multi-scalar politics remains 'state-centric' insofar as it echoes Robert Dahl's republican effort to rid political thinking of its dependency on notions of classical Greek autonomy and singular sovereignty (c.f. Magnusson 2011: 144). On the other hand, Hooghe and Marks's democratic founding of a potentially 'new form of multi-layered governance without clear lines of demarcated jurisdiction and identity' (Schmitter 1998: 132) resonates with Jessop's idea that no final form of governance is possible or desirable - a conception of 'global politics' traceable to the anti-democratic Kant (c.f. Franke 2001: 150). In sum, a Kantian conception of political community can conjure the people, but quite possibly at the cost of the democratic claims made in their name. 
Much governance literature shares international relations' neo-realist illusion that political bodies exist prior to, and independent of, their conditions of action, ${ }^{18}$ but with an important twist. Avant et al. (2010) symptomatically invoke both the idea of bodies pre-existing their milieu and the idea that, in the actions of some privileged bodies, borders are merely spatial, and do not otherwise matter: 'For purposes of this inquiry, global governors are authorities who exercise power across borders for purposes of affecting policy' (Avant et al. 2010: 2, italics in original). Much can be said about a formulation that restricts governing to its effect on policy. In any case, enough has been said thus far, and much more follows, to indicate that for governance generally, and MLG in particular, crossing borders is a highly political moment.

Discussing the 'rational actor' presumption only in the context of international relations discourse would, however, be incomplete and misleading. Barry Hindess (1991) has argued that the idea of an actor as the locus of desires and beliefs - whose actions follow those desires and beliefs - is rife in 'domestic' democratic discourse. This view of the 'rational actor' has a legitimating rather than explanatory or heuristic role. In its place, Hindess proposes 'a more general model in which the actor is conceived simply as a locus of decision and action’ (Hindess 1991: 221).

Rejecting the correlation of freedom and security in sovereignty yields another set of issues for governance. ${ }^{19}$ Hindess $(2001,2005)$ and Helliwell and Hindess (2002) challenge the common defence of liberal government

18 Just such a characterisation of political bodies dominates the discipline of international relations, where it can be characterised as neo-realism. The description holds, even across 'schools' that expend much of their energy (intellectual and otherwise, one suspects) attaching labels to rival schools. Thus it is that, despite claims and counter-claims, the 'English school' of constructivism (see Bull 2002; Bull and Watson 1984; Hurrell and Woods 1999) shares with its largely systems-centred counterpart (e.g. Wight 1977; Wendt 1999; Buzan and Waever 2003; Albert et al. 2001) and many 'postmodern' accounts (e.g. Weber 1995) the basic assumptions concerning political bodies that are relevant to this discussion. Variations within and between positions are, of course, expected and found, and this snapshot is scarcely a survey of international relations as a discipline. But it is, for all that, defensible, as an attentive reading of Rob Walker's now-classic Inside/Outside (1993) would show. Significant, if partial, exceptions to this account include Larner and Walters (2004), Fry and O'Hagan (2000), Soederberg (2005), Baker et al. (2005), and Hobson (2012).

19 Multi-level governance both confirms and challenges sovereign accounts of political bodies, and thus of freedom. For example, governance thinking on security (e.g. Lavenex 2004; Lavenex and Schimmelfennig 2009) tends to accept the Hobbesian/Westphalian claim that the violence of the state is designed (whatever its practical or policy failings) to protect the population within its remit. Security is thus a matter of 'external relations' in relation to other states, or in what is often called 'external governance'. The danger for governance thinking on security is that it will follow the Hobbesian relation of the self and the state, 'associating individual security (safety) and the security of the state (survival) against external aggression' (Bigo 2008: 106). 
as a principled defence of freedom. They show that for certain targets for example, colonial 'indirect rule', the urban poor, migrants, Indigenous populations, the provision of social services - liberalism finds it practical or necessary to govern coercively; i.e. through unfreedom. ${ }^{20}$

Indeed, as in Kant's developmental division of peoples within a 'world' of states, there is an important sense in which the system of states is governed; this, despite the legitimating myth of the Westphalian state (c.f. Hunter 2001; Hobson 2013; Waters 2009), upon which MLG literature depends for its understanding of sovereignty and its transformations. The novelty of the present is not to be found in the application of non-state actors to government, as the concept of governance would have it: evidence of this rule by non-state actors is plentiful in the historical literature. ${ }^{21}$

What is new since at least the end of World War II is a significant challenge in the organisation of Western government to the idea of the state as 'the highest of all' forms of political community (Aristotle's phrase), a challenge that is most clearly made by an extension of governmentality to the system of states (Hindess 2005: 407). Hindess is acutely aware of stretching the Foucauldian concept of governmentality beyond its presumed purview, the national state. ${ }^{22}$ What permits this extension is, in part, Foucault's analysis of the 'art of government'. ${ }^{23}$ The art in question practises a refusal of Hobbes's reduction of politics to institutions licensed by a singular sovereign authority.

Refusing the ideal of a singular sovereign authority has ambiguous consequences for governance. The tension between two loci of 'the highest' - the state and the system of states - points to a neglected aspect of 'the selfgoverning community of citizens' as a useful fiction for political theory and practice. In political designs where rule is not simply authoritarian

20 Far from expressing hypocrisy (the view of Said 1993) or inconsistency (Pitts 2005) in the application of a principle, in Hindess' view liberalism is better seen in Michel Foucault's terms as 'the work of government'. When viewed in this way, the Foucauldian idea that liberalism 'governs through freedom' (Foucault 2008: 63) can also be tested. The result is that, seen as the work of government, which encompasses many non-state actors, authoritarian rule (the 'government of unfreedom') may well serve the aims of liberalism. Moreover, the work of government is not confined to the 'domestic' sphere.

21 Hindess (2005: 405-06); c.f. Raeff (1975).

22 A political a priori many of Foucault's followers forget; see also Walters and Haahr (2005); Walters (2011).

23 For a lucid description, see Magnusson (2011: 91-110). 
(as it is in Hobbes), this fiction is in part maintained by another: the fiction of a common culture, such as appears in the Roman republic or in John Locke's law of opinion and reputation (Hindess 1992, 1997).

It is an open question whether governance serves to create a fiction of a common culture for the state/system of states (Pagden's position above), or whether the indeterminacy of this aporetic relation permits acts of political founding that may intimate unforeseen political transformations. Earlier, I suggested the latter possibility in the context of MLG's capacity to at least conceptually redeploy the Kantian sovereignty/ government distinction, and to 'create a people'.

In this creation, freedom is centrally at issue. Foucault's emphasis on the important role of the government of the self in political rationality raises again the question of causality introduced earlier in the discussion of MLG as a form of political theory. Consider Foucault's insistence that the governmental self is not to be treated as a substance (as in the rational actor model), but as a (variable) form. ${ }^{24}$ As form, the self ('the subject') may well move in a realm of coercion (i.e. be in some respects amenable to a causal account), but this does not exhaust understanding of what is involved. Lacking an a priori substance or nature, the self is 'a practice of freedom', not a self-identity.

\section{The sovereign people}

We can now return to the question of the role that non-causal reasoning 25 plays in MLG and in sovereignty. I suggest a connection between the noncausal account of transformation in MLG and the non-causal dimension of the self in freedom as the work of government. Both non-causal elements contribute to the authorisation and legitimation of the people.

Foucault's rejection of Hobbes's classic account of sovereignty has been noted above (see also Foucault 2003; Neal 2004). As we will see below, despite the considerable value of his critique, Foucault has failed - in common with influential liberal scholarship on Hobbes (e.g. Skinner 1996, 2008; Pettit 2008) - to consider the central role of form in Hobbes's

\footnotetext{
24 See Foucault (1997: 290-91); c.f. Veyne (1997).

25 By 'non-causal' I do not refer to Quentin Skinner's neo-Kantian reasoning on speech-act theory; on this aspect of Skinner's work, see Hindess (2014: 48-49).
} 
argument. The cost of this omission in the case of liberal thought, particularly in its republican variety, is a failure to consider the idea of freedom, and thus democracy, as governed by form in the complex of self, state and system of states. Our account of MLG has revealed the centrality of this complex. It has also shown that MLG can be comprehended as a practice of founding, of establishing (authorising and legitimating) a 'people' (a demos). Might the non-causal character of MLG's legitimating reasoning be seen as a treatment of boundary-crossing as form?

Indeed it might. In this section I seek to show that Hobbes can also in fact, should - be read as performing this very action of authorisation and legitimation. I use the example of Richard Tuck's attempt to discern a defence of a certain condition of democracy in Hobbes's authoritarian reasoning. Following Bodin's earlier insistence that sovereignty must be perpetual (uninterrupted) to be at all, Hobbes solves the problem, according to Tuck, of how sovereignty can subsist when the sovereign is unable to give commands, such as when asleep. During this time, the sovereign delegates power to some other body for the duration, taking it back upon waking. 'Just so a people, on the election of a temporary Monarch, retains the right of meeting again at a certain time and place, and on that day resumes its power' (Hobbes in Tuck 2006: 189).

For Tuck, democracy can be called a 'sleeping sovereign' in this sense, handing over administrative power to another authority of whatever sort (say, the US Congress or the Australian parliament) on condition that it has designated a time and place (e.g. elections) to take back that power. Such a Hobbesian form of democracy accords, in Tuck's view, with the constitution of revolutionary France, now 'the standard view of democratic constitutions in the modern world,' but first articulated by Hobbes (Tuck 2006: 189-90).

Tuck's account of Hobbesian democracy relies on Hobbes's De Cive (On the Citizen, 1647); Tuck's argument may be refined in his forthcoming work, The Sleeping Sovereign (2015), especially in light of criticism (e.g. by Hoekstra (2006) in the same volume as Tuck's essay). As an authorisation of representative democracy, Tuck's use of Hobbesian sovereignty is powerful, despite concerns by fellow liberal theorists. But it fails, in my view, as an account of Hobbes's reasoning. 
So too does Phillip Pettit's attempt to explain how Hobbes founds a people in his account of the move from 'the state of nature' to the commonwealth and the establishment of sovereignty. Pettit's individual is an assumed, unproblematic category. But 'the people', as such, actually fall short of presence in his account, since they exist only after the sovereign is instituted - and if the multitude cannot authorise anything, then what/ who are the 'all individuals, each and every one, that contracts the escape from the state of nature?' (Pettit 2008: 123).

Answers will only be found by attending to the whole of Hobbes's thought. Here, answers concern the ideas of form, freedom and bodies that make sovereignty work. Without this explanation, conceptualising the relation between sovereignty and governance as border-crossing politics remains seriously incomplete.

Acknowledging the inseparability of Hobbes's science of motion and politics (c.f. Slomp 2000; Hänninen 2014), and turning to Hobbes's Leviathan's essential chapters on the self, we find that Hobbes devotes an early section of the text (Chpt. 2, 'Of Imagination') to dreams. There he attempts to demonstrate his view of sense certainty in a distinction between the dreaming and waking state. This distinction is not easily made, Hobbes says, not least because dreams may present more immediate clarity than the decaying sense of distance from sensations experienced while awake. Nonetheless, causal reasoning operates in both; it is simply reversed: 'our Dreams are the reverse of our waking Imaginations; The motion when we are awake, beginning at one end; and when we Dream, at another' (Leviathan, Chpt. 2).

What enables this account of motion, cause and sensation is Hobbes's conception of bodies. A summary of the salient points will have to suffice (drawn in part from Kerr 2013). In his view of motion, Hobbes distinguishes between bodies and accidents. For Hobbes, knowledge of cause proceeds from knowledge of parts of bodies, not wholes, since parts are indeed accidents. But what are accidents?

For Hobbes, accidents are parts of a body that together constitute a body's nature, though not the actual body. ${ }^{26}$ It is a critical mistake ${ }^{27}$ to read Hobbes as following Aristotle's claim that the whole is prior to its parts: this easily leads to the illusion of a common culture within a

26 c.f. Hobbes (1913: 19-20).

27 e.g. by Bates (2012: 78). 
self-sufficient community, criticised above. Actually, Hobbes can be seen to redescribe Aristotle's idea of 'species' (eidos or form) in a clever criticism of the still-powerful Aristotelian reasoning of his day, in order to account for subject-object relations according to the new dualistic science of Hobbes's contemporary, Galileo. The idea of species includes the concept of ananke, or necessity, which is needed to explain knowledge, but is non-causal.

As hypothetical necessity, ananke does not govern sequences. ${ }^{28}$ Moreover, this view of necessity presupposes freedom, but in a highly conditioned manner: the freedom to do otherwise is faced with a milieu in which no reasonable alternative course of action is available. Such is the ananke that requires free and equal subjects in 'meer nature' to recognise its intolerable nature and agree to contract amongst themselves to establish 'a common Power to keep them all in awe' (Leviathan, Chpt. 13). Yet, this single necessity cannot suffice, beset as it is by logical problems: if the multitude in meer nature is as thoroughly insecure as Hobbes avers, then contract appears impossible; if it is not, then such a drastic agreement seems unnecessary (Walker 2006: 64).

Hobbes's solution is to project the condition of a here and now in meer nature to his auditors, but as a condition in an indefinite past, there among 'the savage peoples of America':

It may peradventure be thought, there was never such a time, nor condition of warre as this; and I believe it was never generally so, over all the world: but there are many places, where they live so now. For the savage people in many places of America, except the government of small Families, the concord whereof dependeth on naturall lust, have no government at all; and live at this day in that brutish manner, as I said before (Leviathan, Chpt. 13).

This passage establishes the basic divisions of space and time, in which some peoples are not quite in the same time as others, later adapted by Kant. To make these divisions work to authorise sovereignty, Hobbes invokes necessity-in-form. To tell the story of the absence of alternative for a move from meer nature to the commonwealth, Hobbes substitutes a set 
of accidents there and then for an imaginary situation here and now. His narrative thus moves backwards, though apparently forwards (from meer nature to the commonwealth), as Rob Walker has brilliantly illustrated. ${ }^{29}$

The reversible causality here is created by ananke, as we saw - and shall see again - when Hobbes discusses dreams. This form governs the logic of sovereignty's founding in several ways, across seemingly sharp divisions in time and space. As the accident of the 'Body Politique' (commonwealth), meer nature too can be seen as ananke. All this is erased, of course, in treatments of Hobbes which misconstrue meer nature as the state of nature' or 'anarchy'.

The Euclidian, geometric logic of ananke at work in Leviathan belies Tuck's effort to appeal to a demos (citizen-people) within a single state: Hobbes's logic of founding is necessarily at once a matter of consent and conquest. Violence and peace are co-terminal in Hobbes's sovereignty a condition of constant and paradoxical motion required by Hobbes's idea of freedom and necessity. As a consequence of his idea, the realm of the several sovereigns is neither 'anarchistic' (analogous to, or identical with, 'the state of nature') nor potentially a realm of 'international society' (cooperation underwritten by universal norms). ${ }^{30}$ Instead, this realm can be understood as Baroque (Hänninen 2014): a realm of 'bare nature' required for the laws of motion governing Hobbes's demos to operate. In brief, Hobbes's commonwealth is always excessive - going beyond itself in order to be.

\section{The liberty of crossing borders}

Naturally, the title of this section can be taken literally, and some important recent work has been done on border-crossing markets (Callon 2007; Hänninen 2013) and peoples (Bigo 2002; Ragazzi 2009). My point is entirely sympathetic to these analyses but with a different emphasis: these themes can also be seen to play out the roles of freedom and equality in founding Hobbes's commonwealth as a practice of sovereignty.

29 esp. Walker (2010: 139-41).

30 Contra Noel Malcolm's (2002: Chpt. 13) reading of 'Hobbes's Theory of International Relations'. 
Hobbes's sovereignty is licensed by far more than a definitional sense of a hierarchical authority within a territorial state with a monopoly on the legitimate means of violence (following 20th-century glosses on state sovereignty). As shown above, Hobbes's bodies cross boundaries of space and time, presence and absence, by splitting the form of bodies from their substance. Hobbes's political bodies are thus not 'bounded' in any simple way. By contrast, contemporary liberal theory sees 'the people' as simply unbounded by statist politics, at least as a regulative ideal (Kant), requiring an institutional moulding (new politics) to bring it into being in an appropriate form (see, for example, Abizadeh 2012). I have indicated the risks of this strategy for MLG in the discussion of Hooghe and Marks's attempt to create/locate 'the people' above. I have also indicated, in the context of Kant and governance, that the freedom and equality of the demos are not credible claims. In this section I suggest that the salient source for these claims is no less than Hobbes - the very thinker against whom liberal claims to freedom and equality are made.

It is an article of scholarly faith that Hobbes's account of bodies including the commonwealth he hopes to establish - is deterministic. Most accounts infer from this that liberty must end once obligation is begun. This faith cannot, however, account for Hobbes's reasoning on how consent is established in sovereign domination.

The main target of liberal critiques, and the main point of justification for their versions of liberty, is Hobbes's formulation of sovereignty by institution (consent/contract) and by acquisition (conquest). Like Foucault (2003: 96), these commentators take Hobbes to be arguing that there is no interesting difference between these types of sovereignty. This hasty reading of Hobbes is a fatal mistake if we want to understand how Hobbes's sovereignty works. In Skinner's version, as with Pettit, Hobbes is understood to be arguing for a view of freedom that excludes subjection to rule, leaving the scope for liberty extremely narrow, perhaps no more than the right to the means of self-preservation. Evidence is offered in Hobbes's statement (Leviathan, Chpt. 21) that:

There is written on the Turrets of the city of Luca in great characters at this day, the word LIBERTAS; yet no man can thence inferre, that a particular man has more Libertie, or Immunitie from the service of the Commonwealth there, than in Constantinople. Whether a Commonwealth be Monarchicall, or Popular, the Freedome is still the same. 
Explanatory appeals are also made to the silence of the law; that is, Hobbesian liberty consists in whatever the sovereign leaves unsaid. But is this what Hobbes says? He seems to say the opposite: liberty is identical in Constantinople and Luca because the liberty in question is directed 'externally', towards resisting or invading others from outside, as the preceding sentence in the passage (Leviathan, Chpt. 21) says:

The Athenians, and Romanes, were free; that is, free Commonwealths: not that any particular men had the Libertie to resist their own Representative; but that their Representative had the Libertie to resist, or invade other people.

Sovereignty is not silent here, yet it is the condition of the liberty of particular people. Moreover, the passage is drawing a connection between sovereignty by institution and by acquisition, and thus between 'state sovereignty' and relations between sovereigns. How is this achieved?

Sovereignty by acquisition (conquest, or victory) is also a founding, a beginning of sovereignty - a feature commentators oddly ignore. Charles Tarlton (1999) is one of the few to notice that a split takes place in Leviathan, where all at once sovereignty as such (the covenant or 'contract') divides into two types, institution and acquisition. The latter includes Despotical dominion (Chpt. 19),

when the Vanquished, to avoyd the present stroke of death, covenanteth either in expresse words, or by other sufficient signes of the Will, that so long as his life, and the liberty of his body is allowed him, the Victor shall have the use thereof, at his pleasure.

The passage is curious as it is unclear whether the victorious sovereign is a party to the covenant - if the answer is yes, then the basic procedure of 'exit' from Hobbes's meer nature into the commonwealth is no longer applicable. If not, does the covenant still establish a commonwealth - and how could this work with the victorious sovereignty already established? Moreover, the preservation appears to be merely 'bare life', rather less than is promised by Hobbes's initial picture of sovereignty's benefits. Does sovereignty have a different composition under diverse circumstances of founding? Hobbes cannot allow this: sovereignty is identical, and sovereigns are formally equal.

None of these questions are answered by attending to the concept of servitude Hobbes goes on to describe as a result of this covenant. Tarlton is not much interested in these questions either; his claim is that Hobbes is 
hypocritical. The two forms of sovereignty are very different, and the brute facticity of 'despotical domination' is the truth of the merely hypothetical, verbal concept of sovereignty as covenant and consent offered early in the text.

In addition to charges of hypocrisy, some describe Hobbes's argument as 'paradoxical' (Springborg 2009) and others as 'political, not metaphysical' (Baumgold 2005, 2009) - a procedure we have seen in legitimations of liberalism as a principled defence of freedom, despite its endorsement of authoritarian rule. There is another answer, however: Hobbes's Leviathan is an entirely consistent text. The 'magic instant' (Walker 2010) of founding sovereignty is actually always multiple, crossing the borders of subjective knowledge, science, worlds before and after politics, freedom and necessity, and between sovereigns. The last border-crossing is especially important and hard to grasp. Through the ananke of bodies, Hobbes effects the founding of a single sovereignty and relations between sovereignties in a single stroke. The problem for later thinkers of the logical priority of the state or the system of states largely derives from Hobbes's move here.

Like meer nature and the commonwealth, the end is in the beginning at the present stroke of death. But where in the establishment of the commonwealth do the multitude surrender (give up their rights in a mutual covenant) and 'then' submit to the sovereign thus created (all this appears in a single instant, as Rob Walker (2010) stresses)? In the case of conquest, bodies submit 'first', and then surrender. These appear equivalent: all that differs, says Hobbes, is the location of fear (it sits among the multitude in the former case, but between the multitude and the sovereign in the latter). Yet, we can, from Leviathan's point of view, explain this by observing that, in a reversal of the founding dream of consent, the dream of conquest demands that the bodies' fear causes an image of the sovereign to appear.

Dreams must have a place, if a sovereign is to be a person(s), and yet be perpetual - in this sense Hobbes's Leviathan is a manual for a sovereignty that never sleeps: the dream is written from a waking point of view. Contra Tuck $(2006,2015)$, dreams do not register a reserve power of 'the people'. If anything, the reversible relation of conquest and consent that establishes sovereignty as simultaneously within a single polity and between them points to an inhuman view of the sovereign people, whose ever-wakefulness knows only a non-dream. 
It is significant in this context that William Burroughs precisely describes America not as a utopia or nightmare, but as a non-dream (Burroughs and Odier 1974: 102-08). For all the talk of America as a 'post-sovereign empire', reluctant or otherwise (c.f. Hardt and Negri 2000), Burroughs' insight suggests that this discourse is well off the mark. Yet, if aspects of America resonate with Hobbes's version of sovereign subjectivity, that certainly does not allow it to be contrasted with a 'Kantian Europe'.

In this context it is helpful to be reminded that the inscription of sovereignty in conquest arising from bodies can also be questioned on its claims to universality. Reminding us of the hegemony of a singular conception of freedom and equality in politics, Christine Helliwell (2000) has argued convincingly that the prevalent liberal feminist fear of violence as arising from sexual differences in bodies (which is strikingly similar to the Hobbesian dream that brings forth the conquering sovereign) should not be imposed on societies such as the Gerai of Borneo, who do not dream of sexual difference, nor have nightmares of rape. The more general point is that imagining a people, a way of life or political formation opposed to sovereignty is self-defeating. Sovereign lines of separation do not place things on one side or the other: the founding line has only one side.

Hobbes's dream of conquest in effect turns reason inside-out, rather like the single-sided line of a Möbius strip (c.f. Bigo and Walker 2007): carrying the waking logic of ananke into sleep, the dream appears as if exterior to the familiar, daily experience of the commonwealth. As a founding act of reasoning, Hobbes draws lines between the self, the state and the 'several sovereigns' (there is not a world of sovereigns in Hobbes; 'international relations' await Kant, as Walker (2010) recounts) in order to connect them into a single line. That line is the necessity (ananke) of establishing a new form of political community, where 'no viable alternative' (c.f. Hooghe and Marks above) is conceivable. As described, these features of political reason are amenable to a topological analysis, just as Sakari Hänninen (esp. 2014) undertakes in exemplary fashion. ${ }^{31}$

31 This account of Hobbes's founding argument is, of course, far from complete. There is much more to discuss in the composition of sovereignty than space permits. This is particularly true of Hobbes's reasoning on geometry, domination, movement and 'savages'. Nonetheless, these considerations which I shall treat extensively elsewhere - support the more limited account given here. 


\section{The art of not crossing borders}

This essay has examined some dynamics of recent thought on governance in the EU, as seen through Hobbes's discussion of sovereignty. More specifically, it has looked at some claims to political novelty and democratic potential in the burgeoning literature on MLG. The essay makes three claims in relation to this literature. First, MLG's claims to novelty and democratic enhancement are dependent upon opposition to a flawed conception of sovereignty. Second, this oppositional approach turns out to be self-defeating. Locating sovereignty in a past from which governance has declared independence enables a rhetoric of political founding familiar to classical sovereignty thinking. Third, the response urged to this dilemma was to refuse an oppositional approach to politics. To this end, classical sovereignty in its Hobbesian formulation was revisited. Instead of familiar clichés of three worlds, 'the state of nature, the territorial state and system of states', Hobbes's sovereignty works like MLG: as a bordercrossing conception of politics.

Far from a relegation to the past or an eternal presence, sovereignty as Hobbes argues it remains a contemporary practice. ${ }^{32}$ I have argued that the multiple crossing lines of Hobbesian reasoning appear as one, but we should not be fooled by his authoritarian reasoning. I have also shown that the Hobbesian state is necessarily excessive, going beyond itself: to the 'savages' of the present-past without proper government, to other sovereigns for recognition, and to 'external governance' in the name of 'security and development' (c.f. RAMSI in Fukuyama (2008)). An extended treatment could also examine the excessive state in Hobbes's concern for the welfare of colonies (c.f. Leviathan, Chpt. 22) and to the state's topological stretching via money (Hänninen 2014).

As a boundary-crossing activity, MLG continues to draw on the lines of distinction and connection Hobbes first sketched centuries ago. One implication for further research is that MLG too would benefit from a topological analysis. While governmentality can stretch its forms to take in the system of states and its mutations, governance attempts to reach

32 On this point I am sympathetic to the efforts of other students of sovereignty, including Neil Walker (2003) and Raia Prokhovnik (1999, 2007), and especially Constantin Fasolt (2003). In other respects, like Rob Walker, I try to show that fundamental aspects of sovereignty - in this chapter the focus is on form - are missed by texts that see 'political' and 'legal' sovereignty as the essential objects of analysis. 
'the globe' - not least by crossing its own conceptual borders with state sovereignty and the market. As a future-oriented act of founding political community, reaching for the globe is driven by Hobbes's logic of ananke (form): it appears as both necessary and impossible.

The topological problem is especially serious for MLG's conception of 'the people'. On Hobbes's account of sovereignty, the demos are on the line of border-crossing - eternally trapped in the necessary movement of crossing boundaries in order to be at all. The work of that movement is the fragile foundation of sovereignty's edifice; without it, sovereignty simply falls into incoherence. Conventional accounts construe Hobbesian sovereignty as either fully present or entirely absent (Walker 1993, 2010). The novelty and salience of governance is indexed by the degree to which the opposition between sovereign presence and absence is no longer credible or desirable. Little attention has been paid to the 'mobile permanence' of the people in Hobbesian sovereignty.

Dualistic portrayals of sovereignty and governance miss the role of dualism in politics, to their cost. For example, the title of this section is a nod to the work of James C. Scott $(2009,2013)$, who has long argued that the idea of the state captures much less of the imagination of politically organised peoples than the developmental West assumes (see, in particular, his devastating review of Jared Diamond (Scott 2013)). Where I depart from Scott is in the apparent dualism of his (and others') conception of politics: there is freedom, and there is capture. Hobbes's sovereignty is so powerful precisely because it employs a range of nasty, brutish dualisms to cut short the possibility of escape.

MLG is in a position to challenge sovereignty's work not because of its distance from sovereignty but precisely due to its proximity. MLG attempts to create a people in crossing borders between governance and sovereignty, past and future, the state and the system of states. We can now see MLG's rationality as evolved from Hobbes's. The fixed, frozenin-motion demos of Hobbes's violent, statist authorisations has emerged as a fluid, variable border-crossing demos of global aspirations.

Nothing guarantees that movements in reverse along the line between sovereignty and governance do not or cannot occur. A reversal is not a return to the past: sovereignty as a boundary-crossing politics is a contemporary practice. The prime virtue of MLG may be its capacity to approach this practice as both dangerous and contingent: as authorising a conception of 
freedom and equality that confines 'the people' to an oscillation between mobile permanence and permanent mobility; to approach border-crossing as, in other words, politics. This, it seems to me, is a primary challenge faced by attempts to grasp the senses of transformation at work in social life for more than half a century.

As we began with the image of a train, so we might end with one. This is China Miéville's Iron Council (2004). In a sense it's the inverse of Snowpiercer: a train grown organically with a marvellously heterogeneous group of rebels/marginal/outcasts (i.e. only those inhabiting the rear of Bong's train) fleeing from a ponderously large, violent and corrupt city. As the train returns to the outskirts of the city to meet its historical destiny in a final confrontation with the city's militia, one of the Iron Council's founders, Judah, manages to freeze the train in a 'time golem', somewhat like the 'bug in amber' that Kurt Vonnegut invokes in Slaughterhouse Five. Judah (sure, the reference is clear) has saved the train's denizens from perhaps certain death, but he has also stolen their history - as another founder, Ann-Hari, points out before she shoots Judah for his betrayal. In his freezing of the history of the demos in its perpetual border-crossing, is Hobbes not playing the role of Judah? Between this theological-humanist betrayal and that of Snowpiercer's 'new world order' (which renews the Genesis myth when the heroes derail the train), what shape of train does governance conduct?

\section{References}

Abizadeh, A. (2012). On the Demos and Its Kin: nationalism, democracy, and the boundary problem. American Political Science Review, 106(4): 867-82. doi.org/10.1017/S0003055412000421

Albert, M., Jacobson, D. \& Lapid, Y. (eds) (2001). Identities, Borders, Orders: Rethinking International Relations Theory. University of Minnesota Press, Minneapolis and London.

Arts, B., Lagendijk, A. \& van Houtum, H. (eds) (2009). The Disoriented State: Shifts in Governmentality, Territoriality and Governance. Springer, Berlin.

Avant, D.D., Finnemore, M. \& Sell, S.K. (eds) (2010). Who Governs the Globe? Cambridge University Press. 
Bache, I. \& Flinders M. (2005). Multi-level Governance and British Politics. In: Bache, I. \& Flinders M. (eds) Multi-level Governance, Oxford University Press. pp. 93-106.

__. (eds) (2005). Multi-level Governance. Oxford University Press.

Baker, A., Hudson, D. \& Woodward, R. (2005). Conclusions: financial globalization, multi-level governance and IPE. In: Baker, A., Hudson, D. \& Woodward, R. (eds) Governing Financial Globalization: International Political Economy and Multi-level Governance. Routledge, London and New York, pp. 192-201.

- - (eds) (2005). Governing Financial Globalization: International Political Economy and Multi-level Governance. Routledge, London and New York.

Balme, D.M. (1939). Greek Science and Mechanism I. Aristotle on Nature and Chance. The Classical Quarterly, 33(July/Oct.): 129-38. doi.org/10.1017/S0009838800022308

Bates, D.W. (2012). States of War: Enlightenment Origins of the Political. Columbia University Press, New York.

Baumgold, D. (2005). Hobbes's and Locke's Contract Theories: political not metaphysical. Critical Review of International Social and Political Philosophy, 8(3): 289-308. doi.org/10.1080/13698230500187169

__ (2009). Unparadoxical Hobbes: in reply to Springborg. Political Theory, 37(5): 689-93. doi.org/10.1177/0090591709340141

Bigo, D. (2002). Security and Immigration: toward a critique of the governmentality of unease. Alternatives: Global, Local, Political, 27(Feb.): 63-92. doi.org/10.1177/03043754020270S105

—_. (2008). Security: a field left fallow. In: Dillon, M. \& Neal. A.W. (eds) Foucault on Politics, Security and War. Palgrave MacMillan, Houndmills, pp. 93-114. doi.org/10.1057/9780230229846_5

Bigo, D. \& Walker, R.J.B. (2007). Political Sociology and the Problem of the International. Millennium: Journal of International Studies, pp. 725-40. doi.org/10.1177/03058298070350030401

Brett, A. \& Tully, J. (eds) (2006). Rethinking the Foundations of Modern Political Thought. Cambridge University Press. 
Brown, W. (2005). Edgework: Critical Essays on Knowledge and Politics. Princeton University Press, Princeton and Oxford.

Bull, H. 2002 (1977). The Anarchical Society: A Study of Order in World Politics. 3rd edn. Palgrave, Houndmills.

Bull, H. \& Watson, A. (eds) (1984). The Expansion of International Society. Clarendon Press, Oxford.

Burroughs, W.S. \& Odier, D. (1974). The Job: Interviews with William S. Burroughs. Rev. edn. Grove Press, New York.

Buzan, B. \& Waever, O. (2003). Regions and Powers: The Structure of International Security. Cambridge University Press. doi.org/10.1017/ CBO9780511491252

Callon, M. (2007). An Essay on the Growing Contribution of Economic Markets to the Proliferation of the Social. Theory, Culture and Society, 24(7-8): 139-63. doi.org/10.1177/0263276407084701

Cavallar, G. (2001). Kantian Perspectives on Democratic Peace: alternatives to Doyle. Review of International Studies, 27(2): 229-48. doi.org/10.1017/S0260210500002291

Cerny, P.C. (2009). Neoliberalism and Place: deconstructing and reconstructing borders. In: Arts, B., Lagendijk, A. \& van Houtum, H. (eds) The Disoriented State: Shifts in Governmentality, Territoriality and Governance. Springer, Berlin, pp. 13-40.

Dale, R. (2004). Forms of Governance, Governmentality and the EU's Open Method of Coordination. In: Larner, W. \& Walters, W. (eds) Global Governmentality: Governing International Spaces. Routledge, London and New York, pp. 174-94.

Deleuze, G. (1993). One Manifesto Less. In: Boundas, C.V. (ed.) The Deleuze Reader. Columbia University Press, New York, pp. 204-22.

Dighe, R.S. (ed.) (2002). The Historian's 'Wizard of Oz': Reading L. Frank Baum's Classic as a Political and Monetary Allegory. Greenwood Press, Westport, CT.

Doyle, M.W. (1983a). Kant, Liberal Legacies, and Foreign Affairs. Philosophy and Public Affairs, 12(Summer): 205-35. 
—_. (1983b). Kant, Liberal Legacies, and Foreign Affairs, Part 2. Philosophy and Public Affairs, 12(Autumn): 323-53.

—_. (1986). Liberalism and World Politics. The American Political Science Review, 80(4): 1151-69. doi.org/10.1017/S0003055400185041

Fasolt, C. (2003). The Limits of History. University of Chicago Press.

Foucault, M. (1997). The Ethics of the Concern for the Self as a Practice of Freedom. In: Foucault, M. Ethics: Subjectivity and Truth. The Essential Works of Michel Foucault 1954-1984, Volume One. Rabinow, P. (ed.) The New Press, New York, pp. 281-301.

—_. (2003). Society Must Be Defended: Lectures at the College de France, 1975-76. Macy, D. (trans.) Penguin, London.

- - (2007). Security, Territory, Population: Lectures at the College de France, 1977-1978. Senellart, M. (ed.), Burchell, G. (trans.) Palgrave MacMillan, Houndmills.

- - (2008). The Birth of Biopolitics: Lectures at the College de France, 1978-1979. Senellart, M. (ed.), Burchell, G. (trans.) Palgrave MacMillan, Houndmills and New York.

Franke, M.F.N. (2001). Global Limits: Kant, International Relations and Critique of World Politics. SUNY, New York.

Fry, G. \& O'Hagan, J. (eds) (2000). Contending Images of World Politics. MacMillan Press, Houndmills.

Fukuyama, F. (2008). State-Building in the Solomon Islands, Pacific Economic Bulletin, 23(3): 18-34.

George, S. (2005) Multi-level Governance and the European Union. In: Bache, I. \& Flinders, M. (eds) Multi-level Governance. Oxford University Press, pp. 107-26.

Goodin, R.E. (2008). Innovating Democracy: Democratic Theory and Practice after the Deliberative Turn. Oxford University Press. doi.org/ 10.1093/acprof:oso/9780199547944.001.0001

Goodwyn, L. (1976). Democratic Promise: The Populist Moment in America. Oxford University Press, London and New York. 
Hänninen, S. (2009). Politics of Security in an Age of Anxiety: the double-bind between freedom and control. In: Scheinin, M. (ed) Law and Security: Facing the Dilemmas. EUI Working Paper LAW 2009/11. European University Institute, San Domenico di Fiesole, Italy, pp. 7-22.

- (2013). Neoliberal Politics of the 'Market'. No Foundations: An Interdisciplinary Journal of Law and Justice, 10: 40-58, www.helsinki. fi/nofo/NoFo10HANNINEN.html [Accessed: 01/05/2014].

- (2014). Thomas Hobbes Reading the EU as a Polity. In: Fichera, M., Hänninen, S. \& Tuori, K. (eds) Polity and Crisis: Reflections on the European Odyssey. Ashgate, Farnham, pp. 111-34.

Hardt, M. \& Negri, A. (2000). Empire. Harvard University Press, Cambridge, MA, and London.

Helliwell, C. (2000). 'It's only a Penis': rape, feminism, and difference. Signs, 25(3): 789-816. doi.org/10.1086/495482

Helliwell, C. \& Hindess, B. (2002). The 'Empire of Uniformity' and the Government of Subject Peoples. Cultural Values, 6(1): 137-50. doi.org/ $10.1080 / 1362517022019784$

- (2011). The Past in the Present. Australian Journal of Politics and History, 57(3): 377-88. doi.org/10.1111/j.1467-8497.2011.01603.x

- (2015). Kantian Cosmopolitanism and Its Limits. Critical Review of International Social and Political Philosophy, 18(1): 26-39. doi.org/ 10.1080/13698230.2014.995499

Héritier, A. \& Rhodes, M. (eds) (2011). New Modes of Governance in Europe: Governing in the Shadow of Hierarchy. Palgrave MacMillan, Houndmills.

Hindess, B. (1991). Rationality and Modern Society. Sociological Theory, 9(2) (Autumn): 216-27. doi.org/10.2307/202085

- (1992). Power and Rationality: the Western concept of political community. Alternatives: Global, Local, Political, 17(2): 149-63. doi.org/10.1177/030437549201700201

- (1997). Discourses of Power: From Hobbes to Foucault. Blackwell, Oxford. 
- . (2001). The Liberal Government of Unfreedom. Alternatives: Global, Local, Political, 26(2): 93-111. doi.org/ 10.1177/030437540102600201

_—_. (2002). Neo-Liberal Citizenship. Citizenship Studies, 6(2): 127-43. doi.org/10.1080/13621020220142932

—_. (2005). Politics as Government: Michel Foucault's analysis of political reason. Alternatives: Global, Local, Political, 30(4): 389-413. doi.org/10.1177/030437540503000401

—_. (2014). Bringing Metaphysics Back In? History of European Ideas, 40(1): 44-49. doi.org/10.1080/01916599.2013.784032

Hobbes, T. (1913). The Metaphysical System of Hobbes in Twelve Chapters from Elements of Philosophy Concerning Body Together with Briefer Extracts from Human Nature and Leviathan. Open Court Publishing, Chicago.

_- (1651). Leviathan. MacPherson, C.B. (ed. and 'Introduction') (1985). Penguin, London.

- - (1647). On the Citizen. Tuck, R. \& Silverthorne, M. (ed. and trans.) (2003), Cambridge University Press.

Hobson, J.M. (2012). The Eurocentric Conception of World Politics: Western International Theory, 1760-2010. Cambridge University Press. doi.org/10.1017/CBO9781139096829

__ (2013). The Other Side of the Westphalian Frontier. In: Seth, S. (ed.) Postcolonial Theory and International Relations: A Critical Introduction. Routledge, London and New York, pp. 32-48.

Hoekstra, K. (2006). A Lion in the House: Hobbes and democracy. In: Brett, A. \& Tully, J. (eds) Rethinking the Foundations of Modern Political Thought. Cambridge University Press, pp. 191-218. doi.org/ 10.1017/CBO9780511618376.012

Hooghe, L. \& Marks, G. (2003). Unravelling the Central State, But How? Types of multi-level governance. American Political Science Review, 97(2): 233-43. 
Hunter, I. (2001). Westphalia and the Desacralisation of Politics. In: Hindess, B. \& Jolly, M. (eds) Thinking Peace, Making Peace. Occasional Paper Series 1/2001. Academy of the Social Sciences in Australia, Canberra, pp. 36-44.

Huntington, S.P. (1968). Political Order in Changing Societies. (2006). Yale University Press, New Haven.

Hurrell, A. \& Woods, N. (eds) (1999). Inequality, Globalization, and World Politics. Oxford University Press.

Jessop, B. (2005). Multi-level Governance and Multi-level Metagovernance. In: Bache, I. \& Flinders, M. (eds) Multi-level Governance. Oxford University Press, pp. 49-74.

- (2009). From Governance to Governance Failure and from Multilevel Governance to Multi-scalar Meta-governance. In: Arts, B., Lagendijk, A. \& van Houtum, H. (eds) The Disoriented State: Shifts in Governmentality, Territoriality and Governance. Springer, Berlin, pp. 79-100. doi.org/10.1007/978-1-4020-9480-4_4

Kant, I. (1975). Perpetual Peace. In: Beck, L.W. (ed.); Beck, L.W., Anchor, R.E. \& Fackenheim, E.L. (trans.) Immanuel Kant. Kant on History. Bobbs-Merill, Indianapolis, pp. 85-136.

Kerr, R. (2013). Sovereignty Never Sleeps. Paper presented to the Finnish Political Science Association Annual Conference, 7-8 March, University of Lapland, Rovaniemi, Finland.

Larner, W. \& Walters, W. (eds) (2004). Global Governmentality: Governing International Spaces. Routledge, London and New York.

Lavenex, S. (2004). EU External Governance in 'Wider Europe'. Journal of European Public Policy, 11(4): 680-700. doi.org/ 10.1080/1350176042000248098

Lavenex, S. \& Schimmelfennig, F. (2009). EU Rules beyond EU Borders: theorizing external governance in European politics. Journal of European Public Policy, 16(6): 791-812. doi.org/ 10.1080/13501760903087696

Lee, D. (2013). 'Office Is a Thing Borrowed': Jean Bodin on offices and seigneurial government. Political Theory, 41(3): 409-40. doi.org/ $10.1177 / 0090591713476050$ 
Lob, J. \& Rochette, J.-M. (2014). Snowpiercer Volume 1: The Escape. 2014 edn, Selavy, V. (trans.) Titan Comics, London.

MacMillan, J. (2004). Liberalism and the Democratic Peace. Review of International Studies, 30(2): 179-200. doi.org/10.1017/ s026021050400600x

Magnusson, W. (2011). Politics of Urbanism: Seeing Like a City. Routledge, Milton Park.

Malcolm, N. (2002). Aspects of Hobbes. Oxford University Press. doi.org/ $10.1093 / 0199247145.001 .0001$

Marks, G., Scharpf, F.W., Schmitter, P.C. \& Streeck, W. (eds) (1998). Governance in the European Union. Sage Publications, London.

McGuire, M.C. \& Olson Jr, M. (1996). The Economics of Autocracy and Majority Rule: the invisible hand and the use of force. Journal of Economic Literature, 34(1): 72-96.

Miéville, C. (2004). The Iron Council. (2011), Pan Books, London.

Neal, A.W. (2004). Cutting Off the King's Head: Foucault's Society Must Be Defended and the problem of sovereignty. Alternatives: Global, Local, Political, 29(4): 373-98. doi.org/10.1177/030437540402900401

Olson, M. (1971). The Logic of Collective Action: Public Goods and the Theory of Groups. Harvard University Press, Cambridge, MA.

- - (1993). Dictatorship, Democracy, and Development. American Political Science Review, 87(3): 567-76. doi.org/10.2307/2938736

Pagden, A. (1998). The Genesis of 'Governance' and Enlightenment Conceptions of the Cosmopolitan World Order. International Social Science Journal, 50(Mar.): 7-15. doi.org/10.1111/1468-2451.00105

- - (2001). Peoples and Empires: A Short History of European Migration, Exploration and Conquest, from Greece to the Present. The Modern Library, New York.

Palonen, K. (2002). The History of Concepts as a Style of Political Theorizing: Quentin Skinner's and Reinhart Koselleck's subversion of normative political theory. European Journal of Political Theory, 1(1): 91-106. doi.org/10.1177/1474885102001001007 
— - (2003). Four Times of Politics: policy, polity, politicking, and politicization. Alternatives: Global, Local, Political, 28(2): 171-86. doi.org/10.1177/030437540302800202

Pettit, P. (2008). Made with Words: Hobbes on Language, Mind and Politics. Princeton University Press.

Pitts, J. (2005). A Turn to Empire: The Rise of Imperial Liberalism in Britain and France. Princeton University Press. doi.org/10.1515/ 9781400826636

Pogge, T.W. (1992). Cosmopolitanism and Sovereignty. Ethics, 103(1): 48-75. doi.org/10.1086/293470

- (1994). An Egalitarian Law of Peoples. Philosophy and Public Affairs, 23(Summer): 195-224. doi.org/10.1111/j.1088-4963.1994. tb00011.x

—. (2002). World Poverty and Human Rights. Oxford University Press.

Prokhovnik, R. (1999). The State of Liberal Sovereignty. The British Journal of Politics and International Relations, 1(1): 63-83. doi.org/ 10.1111/1467-856X.00004

- (2007). Sovereignties: Contemporary Theory and Practice. Palgrave MacMillan, Basingstoke. doi.org/10.1057/9780230593527

Raeff, M. (1975). The Well-Ordered Police State and the Development of Modernity in Seventeenth- and Eighteenth-Century Europe: an attempt at a comparative approach. The American Historical Review, 80(5): 1221-43. doi.org/10.2307/1852058

Ragazzi, F. (2009). Governing Diasporas. International Political Sociology, 3(4): 378-97. doi.org/10.1111/j.1749-5687.2009.00082.x

Rawls, J. (1985). Justice as Fairness: political not metaphysical. Philosophy and Public Affairs, 14(3): 223-51.

—_. (1996). Political Liberalism. Columbia University Press, New York.

- (1999). The Law of Peoples. Harvard University Press, Cambridge, MA.

Rockoff, H. (1990). The 'Wizard of Oz' as a Monetary Allegory. Journal of Political Economy, 98(4): 739-60. doi.org/10.1086/261704 
Rosato, S. (2003). The Flawed Logic of Democratic Peace Theory. American Political Science Review, 97(4): 585-602. doi.org/10.1017/ S0003055403000893

Said, E.W. (1993). Culture and Imperialism. Alfred A. Knopf, New York.

Scharpf, F.W. (2012). Legitimacy Intermediation in the Multilevel European Polity and Its Collapse in the Euro Crisis. Max-Planck-Institute für Gesellschaftsforschung Discussion Paper 12/6, October, Cologne.

Schmitter, P.C. (1998). Imagining the Future of the Euro-Polity with the Help of New Concepts. In: Marks, G., Scharpf, F.W., Schmitter, P.C. \& Streeck, W. (eds) Governance in the European Union. Sage Publications, London, pp. 121-50.

Scott, J.C. (2009). The Art of Not Being Governed: An Anarchist History of Upland Southeast Asia. Yale University Press, Chicago.

__. (2013). Crops, Towns, Government (Review of Diamond, J. The World until Yesterday). London Review of Books, 35(22): 13-15, www.lrb.co.uk/v35/n22/james-c-scott/crops-towns-government [Accessed: 15/11/13].

Skinner, Q. (1996). Reason and Rhetoric in the Philosophy of Hobbes. Cambridge University Press. doi.org/10.1017/CBO9780511598579

- (2008). Hobbes and Republican Liberty. Cambridge University Press.

Slomp, G. (2000). Thomas Hobbes and the Political Philosophy of Glory. St. Martin's Press, New York. doi.org/10.1057/9780333984437

Soederberg, S. (2005). The New International Financial Architecture (NIFA): an emerging multi-level structure of neo-liberal capitalism. In: Baker, A., Hudson, D. \& Woodward, R. (eds) Governing Financial Globalization: International Political Economy and Multi-level Governance. Routledge, London and New York, pp. 171-89.

Sorell, T. (2000). Hobbes's Uses of the History of Philosophy. In: Rogers, G.A.J. \& Sorell, T. (eds) Hobbes and History. Routledge, London, pp. 81-95.

Springborg, P. (2009). The Paradoxical Hobbes: a critical response to the Hobbes symposium. Political Theory, 37(5): 676-88. doi. org/10.1177/0090591709340140 
—. (2010). Liberty Exposed: Quentin Skinner's Hobbes and republican liberty. British Journal for the History of Philosophy, 18(1): 139-62. doi.org/10.1080/09608780903339277

Tarlton, C.D. (1999). 'To avoid the present stroke of death': despotical domination, force, and legitimacy in Hobbes' Leviathan. Philosophy, 74(2): 221-74. doi.org/10.1017/S0031819199000273

Tuck, R. (2006). Hobbes and Democracy. In: Brett, A. \& Tully, J. (eds) Rethinking the Foundations of Modern Political Thought. Cambridge University Press, pp. 170-90. doi.org/10.1017/cbo97805 11618376.011

- (2015). The Sleeping Sovereign. Cambridge University Press, New York. doi.org/10.1017/CBO9781316417782

Veyne, P. (1997). Foucault Revolutionises History. In: Davidson, A.I. (ed.) Foucault and His Interlocutors. University of Chicago Press, Chicago \& London, pp. 146-82.

Walker, N. (2003). Late Sovereignty in the European Union. In: Walker, N. (ed.) Sovereignty in Transition: Essays in European Law. Hart Publishing, Oxford and Portland, OR, pp. 3-32.

Walker, R.B.J. (1993). Inside/Outside: International Relations as Political Theory. Cambridge University Press.

- (2006). The Doubled Outsides of the Modern International. Ephemera: Theory \& Politics of Organization, 6(1): 56-69.

- (2010). After the Globe, Before the World. Routledge, New York and Oxford.

Walters, W. (2011). Foucault and Frontiers: notes on the birth of the humanitarian border. In: Bröckling, U., Krassman, S. \& Lemke, T. (eds) Governmentality: Current Issues and Future Challenges. Routledge, New York and London, pp. 138-64.

Walters, W. \& Haahr, J.H. (2005). Governing Europe: Discourse, Governmentality and European Integration. Routledge, London and New York. doi.org/10.4324/9780203299722 
Waters, T.W. (2009). 'The Momentous Gravity of the State of Things Now Obtaining': annoying Westphalian objections to the idea of global governance. Indiana Journal of Global Legal Studies, 16(1): 25-58. doi.org/10.2979/GLS.2009.16.1.25

Weber, C. (1995). Simulating Sovereignty: Intervention, the State and Symbolic Exchange. Cambridge University Press.

Wendt, A. (1999). Social Theory of International Politics. Cambridge University Press, New York. doi.org/10.1017/CBO9780511612183

Wight, M. (1977). Systems of States. Leicester University Press.

Ziaukas, T. (1998). Baum's Wizard of Oz as Gilded Age Public Relations. Public Relations Quarterly, 43(3): 7-11. 
This text is taken from Multi-level Governance: Conceptual challenges and case studies from Australia, edited by Katherine A. Daniell and Adrian Kay, published 2017 by ANU Press, The Australian National University, Canberra, Australia.

dx.doi.org/10.22459/MG.11.2017.06 